Jurnal Riset Biologi dan Aplikasinya, Volume 2, Nomor 2, September 2020

Jurnal Riset Biologi dan Aplikasinya

\title{
Defining the Rearing Cage for Agriocnemis femina Damselfly (Odonata, Zygoptera, Coenagrionidae)
}

\author{
Penentuan Kandang Pemeliharaan Capung Jarum Agriocnemis femina \\ (Odonata, Zygoptera, Coenagrionidae)
}

\author{
Muhammad Nazri Janra*, Henny Herwina, Hafizhah Rahmayani, Lily Rahmawati, \\ Dika Putri Sehati, Shania Refka Fandesti \\ Biology Department, Faculty of Mathematics and Natural Sciences, Universitas Andalas
}

\section{Article History \\ Received : 14 June 2020 \\ Approved : 16 August 2020 \\ Published : 30 September 2020 \\ Keywords: Agriocnemis femina; cage setup; feeding; ornamental plants; rearing \\ Kata Kunci: Agriocnemis femina; pengaturan kandang; makanan; tanaman hias; pemeliharaan}

\begin{abstract}
Rearing insects such as dragonflies and damselflies aim to gain uniform progeny that used for scientific purposes. In Indonesia, unfortunately, this rearing type is not yet common which suggests the time for its initiation. This study has objective to define the type of rearing cage for Agriocnemis femina damselfly (Odonata, Zygoptera, Coenagrionidae). It was conducted descriptively by using two smalls (9 x $13 \times 23 \mathrm{~cm})$, four medium $(14 \times 15 \times 22 \mathrm{~cm})$ and two larges $(20 \times 23 \times 33 \mathrm{~cm})$ size boxes as cage setups, with or without ornamental plants in it. The feeding was with limited (10-15 Drosophila flies provided per day) and unlimited provision. Data was analyzed descriptively. The results showed that $A$. femina lived normally, including eating and mating, within the large cage setup equipped with ornamental plants and unlimited feeding.
\end{abstract}

How to cite: Janra, M.N., Herwina, H., Rahmayani, H., Rahmawati, L., Sehati, D.P., \& Fandesti, S.R. (2020). Defining the Rearing Cage for Agriocnemis femina Damselfly (Odonata, Zygoptera, Coenagrionidae). Jurnal Riset Biologi dan Aplikasinya, 2(2), $42-48$.

\begin{abstract}
Abstrak
Pemeliharaan serangga seperti capung dan capung jarum mempunyai tujuan untuk mendapatkan populasi anakan yang seragam yang dapat digunakan lebih lanjut untuk beragam tujuan ilmiah. Sayangnya, hal ini belum banyak dilakukan di Indonesia sehingga perlu untuk mulai diinisiasi. Penelitian ini bertujuan untuk menemukan bentuk kandang pemeliharaan capung jarum Agriocnmeis femina (Odonata: Coenagrionidae). Penelitian dilakukan secara deskriptif dengan menggunakan settingan dua kandang kecil ( $9 \times 15 \times 25 \mathrm{~cm})$, empat sedang $(14 \times 15 \times 22 \mathrm{~cm})$ dan dua besar (20 $\times 25 \times 33 \mathrm{~cm}$ ), dengan atau tanpa meletakkan tumbuhan penghias di dalamnya. Data dianalisis secara deskriptif. Pemberian makanan dilakukan secara terbatas (1015 lalat Drosophila disediakan dua kali sehari) dan tak terbatas. Hasil penelitian menunjukkan capung jarum A. femina hidup dan melakukan aktivitas makan serta kawin secara normal pada kandang besar yang dilengkapi dengan tumbuhan dan dengan pemberian makanan tak terbatas.
\end{abstract}

E*Corresponding Author:

e-ISSN 2655-9927

Jln. Kampus Unand Limau Manis Padang, Sumbar 25163 Indonesia

E-mail:mnjanra@sci.unand.ac.id 


\section{INTRODUCTION}

Dragonflies (including damselflies) are relatively large diurnal insects that have attracted the attention of biologists to learn for many of their biological aspects (Corbet, 1999; Sylsbi, 2001). This insect group has been subjected in many ecological, morphological, behavioral, and evolutionary studies for long time (Tillyard, 1917; Corbet, 1999; Córdoba-Aguilar, 2008). Despite the long history of study on dragonflies, there still unknown aspects about them that need further investigation. Hence, the efforts have been continuously deployed to study it, including with utilization of rearing methodology. Rearing process, theoretically, allows researchers to follow through the development of dragonflies' metamorphosis life stages. Furthermore, many potential benefits can be gained from rearing dragonfly and other insects.

Rearing dragonflies or damselflies are mostly related to certain specific objectives from particular studies and very segmental in some previous studies. It is common to develop larvae found in the field to see all nymph stages and what its imago form emerges (McCullough et al., 2020). The larval and adult dragonfly can be used to simulate the effects of climate change onto aquatic and terrestrial organism (McCauley et al., 2018). Odonata is also viewed as a good model for ecology and evolutionary genomic researches (Bybee et al., 2016), or can be simply used as teaching subject in the classroom (Switzer, 2002).

Rearing damselflies under laboratory condition is promising in order to answer so many biological questions (Gossum et al., 2003). Colonies resulted from laboratory rearing bring some advantages, such as largely uniform in age, genetic, morphological and physiological conditions that reduce experimental variability; they also become steady provision for long-term experiment and they come with high-performance and quality (Roe et al., 2018). As entomophagous insect group, dragonflies and damselflies may become potential pest eradicators (Chambers, 1977). A thorough review for the rearing works on Odonata larvae was provided by (Rice, 2008) with a specific notion of short-term maintenance on libellulidae larvae. Meanwhile, some efforts may have shown prospect in rearing damselflies, such laboratory propagation for Ischnura elegans (Gossum et al., 2003), I. ramburii (Locklin et al., 2012) and I. senegalensis (Okude et al., 2017).

In Indonesia, despite the current massive emergence of interest on Odonata, yet none dedicated to study about the rearing process itself. Hence, this paper discusses the basic needs in doing dragonfly rearing i.e. finding the best cage or container arrangement, a simple yet essential aspect in rearing it (Cohen, 2018). This is a starting point before conducting further rearing process, as the previous studies did not discuss about the detail of rearing cage used therein.

\section{MATERIALS AND METHODS}

\section{Study Species}

This study used wild individuals Agriocnemis femina (Odonata; Coenagrionidae). It is a small damselfly with sexual dimorphism, where both sexes mainly look different in body color; hence it will help in individual and sexual identification (see Figure 1). Young males are in green and black body that slowly turns into white-pruinesce with its maturity with orange abdominal tip, while females are dominantly red (Setiyono et al. 2017). This damselfly is distributed across India, Southeast Asia until Pacific islands where it inhabits human affected habitats and considered as Least Concern species by IUCN Red list (Janra et al. 2020).
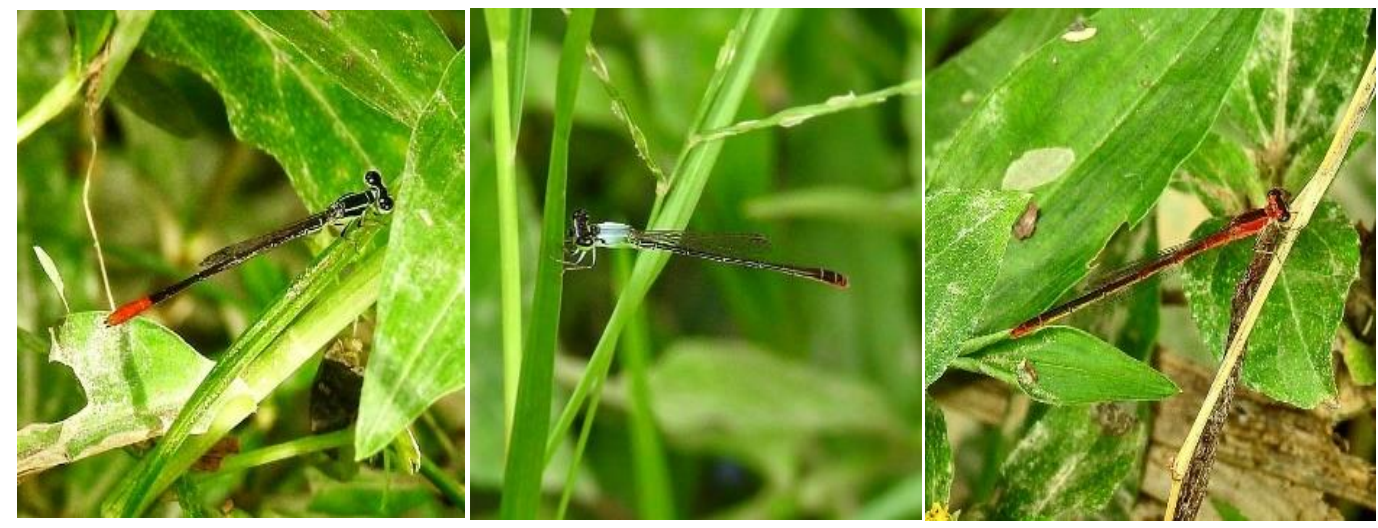

Figure 1. Morphology of Agriocnemis femina: young male (left), adult male (middle) and female (right) 
This damselfly is also non-terrestrial defending with short lifespan of couple weeks since its emergence as an adult (Silsby, 2001). In Padang City, it is easily found in ditches and sewages where it seems to dominate these polluted habitats (Janra and Herwina, in prep.). Male and female adult $A$. femina were collected using an aerial insect net and placed inside a $9 \times 13 \times 23 \mathrm{~cm}$ transporting box, which lid replaced with mosquito wire to enact air circulation.

\section{Rearing set up}

There were three dimensions (height $\mathrm{x}$ width $\mathrm{x}$ length) of boxes used in the trial of rearing cages; two $9 \times 13 \times 23 \mathrm{~cm}$ boxes, four $14 \times 15 \times 22 \mathrm{~cm}$ boxes, and two $20 \times 23 \times 33 \mathrm{~cm}$ boxes (hereinafter small, medium and large boxes or cages). Each box was equipped with twigs intended as perching site for the damselflies and the opening side of the boxes covered with mosquito net. Two small and two medium boxes were left plain without further additional materials inside the cages. The other two medium boxes were equipped with a small water container filled with water spinach (Ipomoea aquatic). The inside of the two large boxes was decorated with living Pogonantherum crinitum (Poaceae) and Sellaginella fern, two common plants found in the ditches around the place of this study undertaken. These plants planted into the inner bottom of boxes using soaked cotton as the growth medium. The moisture of the cotton was maintained with mild water drops from a squeeze bottle. All boxes are arranged near the window facing east in the Laboratory of Animal Taxonomy, Biology Department, Universitas Andalas, Padang. This side of the laboratory receives morning sunlight between 09.00-11.00 hours which ensures that all rearing cages received similar lighting intensity.

Damselflies in small and medium boxes were fed manually once or twice a day with wildly caught Drosophila melanogaster. The flies were capture using a rotten banana as bait, then 10-15 flies placed inside a small tube before inserted into the cage. On the other hand, the feeding in large boxes was arranged differently. Drosophila melanogaster flies were directly attracted to enter the cages by placing a $1.5 \times 10 \mathrm{~cm}$ petri dish contained slices of ripped banana. The mesh size of mosquito wire used to cover the opening of large boxes is small enough to prevent the damselfly from escaping, but passable for Drosophila melanogaster. Hence, within these large boxes, food provision was considerably ad libitum.

\section{Observation and Analysis}

Individuals Agriocnemis femina were kept at 1:2 (female to male) ratio within the rearing cage, with the number of individuals adjusted to the size of cage. The sex ratio used in this study was lower than what was observed in its natural environment, which reached 1:6 (Janra and Herwina, in prep.). The damselflies individuals were marked carefully with Faber-castle ${ }^{\circledR} \quad 0.5 \mathrm{~mm}$ marker pen to assist recognition during observation. The observation, which was conducted in October 2019, focused at which rearing cage type that best to sustain the 'normal' living of damselflies, determined from damselflies' longevity and exhibited behavior. Feeding and mating activities were subjected to observation and recording among the longest survived damselflies. The room temperature as well as temperature in the large rearing cages were simultaneously measured using an alcohol thermometer, while documentation was with Nikon Coolpix P900 and cellular phone camera. Data from observation was then tabulated and descriptively analyzed by comparing it with previous researches as well as giving our elaborated thoughts on it.

\section{RESULTS AND DISCUSSION}

The observation was made from 7-30 October 2019 simultaneously at all rearing cages. The numbers of living individuals in each cage per observation day are presented in Table 1. The damselflies in small and medium rearing cages survived until the first week the longest, while those in large cages remain living slightly beyond the third week (Figure 2). We suspect that the plain set up in small and medium cages provide the least support for damselflies to perch, as the twigs placed within as the perching site was not always preferable for this purpose. The damselflies often were seen flew through the cage space, hit the box's wall, and failure to cling onto the slippery surface of the box and subsequently fell down to the bottom.

The concussion may immobilize the damselfly which later lay motionless at the bottom of the cage. Perching is important for the dragonfly to roost and sustain their body condition (Mazzacano et al., 2014) hence failing from doing it for a while may result in fatality. On the medium cages filled with water spinach, the damselflies lasted a bit longer, however, the water medium for water spinach potentially turned into pitfall trap for fallen damselfly. Upon hitting the box wall, a damselfly can be drowned if fell to the water container. 
It may suggest that equipping rearing cage with water container, despite Odonata affinity to aquatic body, should be limited. Water provision can be an exception for medium where females lay their eggs later, if the rearing succeeded.

The longest living damselflies were observed in large rearing cages, especially cage 1, where its occupants lived throughout October 2019, before found dead the next day. We suspected that the more spacious cages, combined with plants set up inside and abundant food source provided more suitable microenvironment for A. femina damselflies. The stalks of Pogonantherum crinitum and Sellaginella provide comfortable pick for damselflies to perch. Furthermore, the soaked cotton worked together with the ornamental plants in accommodating lower internal temperature in the rearing cages (the average $24.1^{\circ} \mathrm{C}$ and $24.0^{\circ} \mathrm{C}$ respectively in boxes 1 and 2 against $24.3^{\circ} \mathrm{C}$ of room temperature; Figure 3). For insects, that are poikilotherms, surrounding temperature gives immense impact to their physiology that manifests outward into many of their living aspects. Lower rearing cage temperature helps in preventing cannibalism among reared insect, as well as helps them to regulate their internal temperature, a feature that is important in combatting pathogens and maintaining physiology and genetic condition (Bridges, 1933; Carruthers et al., 1992; Hinks \& Erlandson, 1994).

Table 1. Observed longevity of reared Agriocnemis femina damselfly ( $\mathrm{F}=$ female, $\mathrm{M}=$ male)

\begin{tabular}{|c|c|c|c|c|c|c|c|c|c|c|c|c|c|c|c|c|}
\hline \multirow{2}{*}{ Cage type } & \multicolumn{16}{|c|}{ Observation Period on October 2019 (detailed as $\mathrm{n}^{\text {th }}$ day) } \\
\hline & 7 & 8 & 9 & 10 & 13 & 14 & 15 & 16 & 17 & 18 & 19 & 20 & 21 & 24 & 25 & 30 \\
\hline Small 1 & $1 \mathrm{~F} 2 \mathrm{M}$ & $1 \mathrm{~F} 1 \mathrm{M}$ & - & - & - & - & - & - & - & - & - & - & - & - & - & - \\
\hline Small 2 & $1 \mathrm{~F}_{2} \mathrm{M}$ & $1 \mathrm{~F}$ & - & - & - & - & - & - & - & - & - & - & - & - & - & - \\
\hline $\begin{array}{l}\text { Medium } \\
\text { plain } 1\end{array}$ & $1 \mathrm{~F} 3 \mathrm{M}$ & $1 \mathrm{~F} 3 \mathrm{M}$ & $1 \mathrm{~F}_{1} \mathrm{M}$ & $1 \mathrm{M}$ & - & - & - & - & - & - & - & - & - & - & - & - \\
\hline $\begin{array}{l}\text { Medium } \\
\text { plain } 2\end{array}$ & $1 \mathrm{~F} 3 \mathrm{M}$ & $1 \mathrm{~F} 3 \mathrm{M}$ & $1 \mathrm{~F}_{1} \mathrm{M}$ & - & - & - & - & - & - & - & - & - & - & - & - & - \\
\hline $\begin{array}{c}\text { Medium } \\
\text { with plant } \\
1\end{array}$ & $1 \mathrm{~F} 3 \mathrm{M}$ & $1 \mathrm{~F} 3 \mathrm{M}$ & $1 \mathrm{~F} 2 \mathrm{M}$ & $1 \mathrm{~F} 2 \mathrm{M}$ & $1 \mathrm{~F}$ & - & - & - & - & - & - & - & - & - & - & - \\
\hline $\begin{array}{c}\text { Medium } \\
\text { with plant } \\
2\end{array}$ & $1 \mathrm{~F} 3 \mathrm{M}$ & $1 \mathrm{~F} 3 \mathrm{M}$ & $1 \mathrm{~F} 3 \mathrm{M}$ & $1 \mathrm{~F} 3 \mathrm{M}$ & $1 \mathrm{~F} 3 \mathrm{M}$ & $1 \mathrm{~F} 2 \mathrm{M}$ & $1 \mathrm{~F}$ & - & - & - & - & - & - & - & - & - \\
\hline Large 1 & $3 \mathrm{~F} 9 \mathrm{M}$ & $3 \mathrm{~F} 6 \mathrm{M}$ & $3 \mathrm{~F} 6 \mathrm{M}$ & $3 \mathrm{~F} 6 \mathrm{M}$ & $3 \mathrm{~F} 6 \mathrm{M}$ & $3 \mathrm{~F} 6 \mathrm{M}$ & $3 \mathrm{~F} 6 \mathrm{M}$ & $3 \mathrm{~F} 6 \mathrm{M}$ & $2 \mathrm{~F} 3 \mathrm{M}$ & $2 \mathrm{~F} 3 \mathrm{M}$ & $2 \mathrm{~F} 3 \mathrm{M}$ & $2 \mathrm{~F} 3 \mathrm{M}$ & $2 \mathrm{~F} 3 \mathrm{M}$ & $1 \mathrm{~F} 3 \mathrm{M}$ & $1 \mathrm{~F} 1 \mathrm{M}$ & $1 \mathrm{~F} 1 \mathrm{M}$ \\
\hline Large 2 & $2 \mathrm{~F} 6 \mathrm{M}$ & $2 \mathrm{~F} 6 \mathrm{M}$ & $2 \mathrm{~F} 6 \mathrm{M}$ & $2 \mathrm{~F} 6 \mathrm{M}$ & $2 \mathrm{~F} 6 \mathrm{M}$ & $2 \mathrm{~F} 6 \mathrm{M}$ & $2 \mathrm{~F} 6 \mathrm{M}$ & $2 \mathrm{~F} 6 \mathrm{M}$ & $2 \mathrm{~F} 3 \mathrm{M}$ & $2 \mathrm{~F} 3 \mathrm{M}$ & $2 \mathrm{~F} 3 \mathrm{M}$ & $2 \mathrm{~F} 3 \mathrm{M}$ & - & - & - & - \\
\hline
\end{tabular}

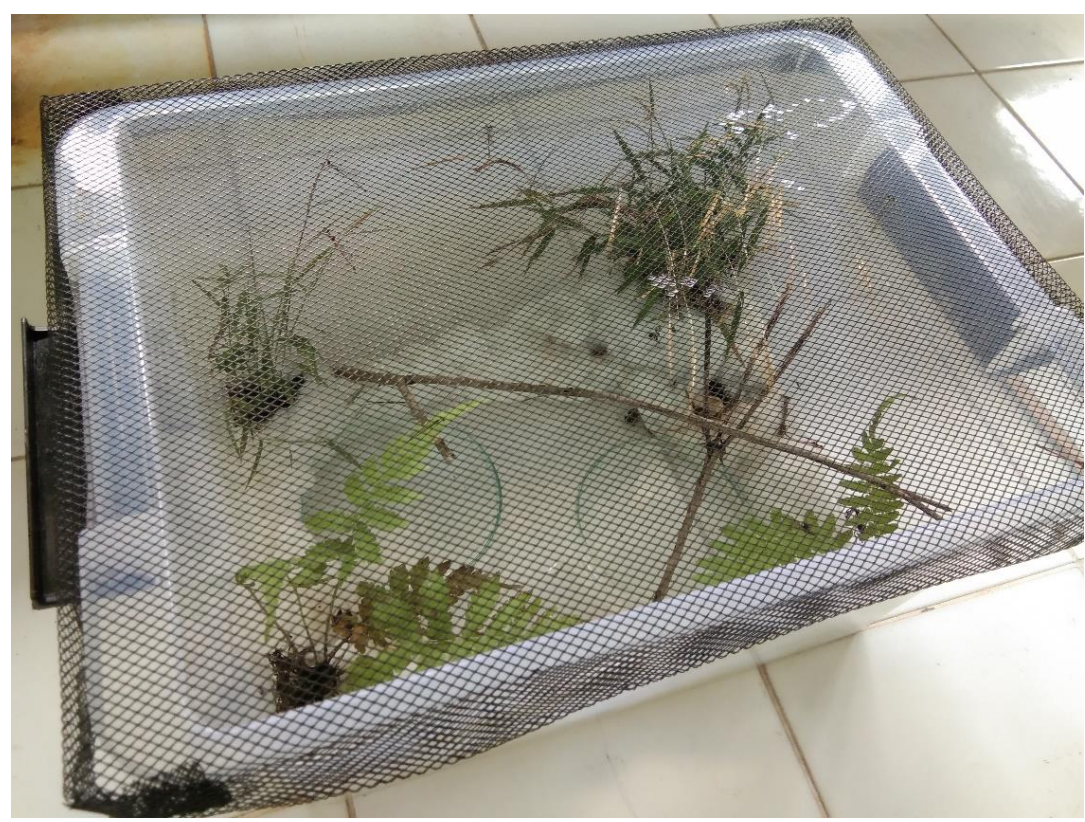

Figure 2. Large cage setup 


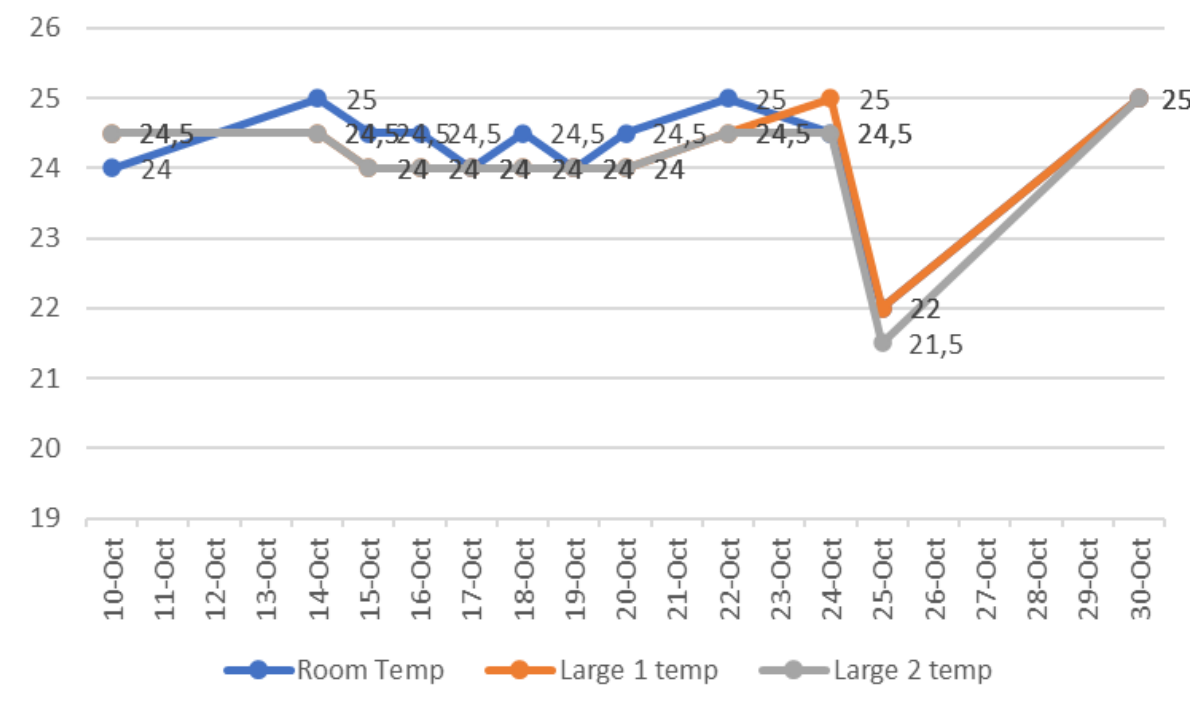

Figure 3. Temperature $\left({ }^{\circ} \mathrm{C}\right)$ recorded in room and large rearing cages during observation

Table 2. Feeding capacity of A. femina on D. melanogaster within 10 minutes of observation

\begin{tabular}{lccccccc}
\hline & \multicolumn{7}{c}{ Observation Period } \\
\cline { 2 - 7 } & 13 -Oct & 16 -Oct & 17 -Oct & 18 -Oct & 20-Oct & $24-$-Oct & 25 -Oct \\
\hline Female(s) & 1 & 2 & 1 & 3 & 1 & 1 & 1 \\
Male & - & - & - & 1 & - & - & - \\
\hline
\end{tabular}

Providing ad libitum food resources by attracting Drosophila melanogaster into the cage was advantageous in reducing interruption to the reared damselflies, as the cage lid did not need to be frequently opened to insert the captured flies. This was the case with other cage setups, as we observed the damselflies stressed out or even tried to escape from the cage during the feeding procedure commenced. This feeding procedure is potentially used as a 'labor-saving' method due to no time needed to prepare Drosophila melanogaster culture, as the flies attracted directly into the cage using the bait of simple banana slices. Simplifying the workload, especially on the mass-rearing of insects, is essential to produce a large amount of progeny on effective cost (Gossum et al. 2003). Upon their profound habituation in the large boxes, a scan sampling series was randomly conducted to see the feeding capacity of $A$. femina on D. melanogaster flies. Scan sampling lasted 10 minutes in each session, by counting how many flies consumed by the damselflies in large rearing cage $\# 1$. The observation is presented in the following Table 2 .

Our data shows that female(s) recorded to feed more frequently than male within the observation time, which only seen feeding once on 18 October. This does not necessarily reflect the significant difference in the feeding rate between sexes, as the male(s) might feed outside the observation time. The feeding system used in this study, despite simplified the workload in providing food, had a flaw in term that the damselflies could feed indiscernibly. Unless a thorough and continuous observation is conducted to draw a full picture on this matter, the feeding rate is sufficiently represented by random scan sampling or observation (Altmann, 1974).

Three individuals D. melanogaster were consumed within the approximate 10 minutes by a female in large cage \#1 on October 2018. Interestingly, this female was seen to have mated on the previous day (Figure 4). The mating, which occurred for more than four minutes during midday 17 October, became the only successful mating observed in this study. Since then, up until the observation concluded on 30 October, males attempted to approach females but ended up in unsuccessful mating. Albeit the observation failed to notice if female laid eggs, this mating alone indicated the acceptance of $A$. femina damselflies to the rearing setup. The elevated feeding rate on females has been previously reported as part of post-nuptial behavioral changes in most insect species (Carvalho et al., 2006; Perry, 2011; Tsukamoto et al., 2014). 


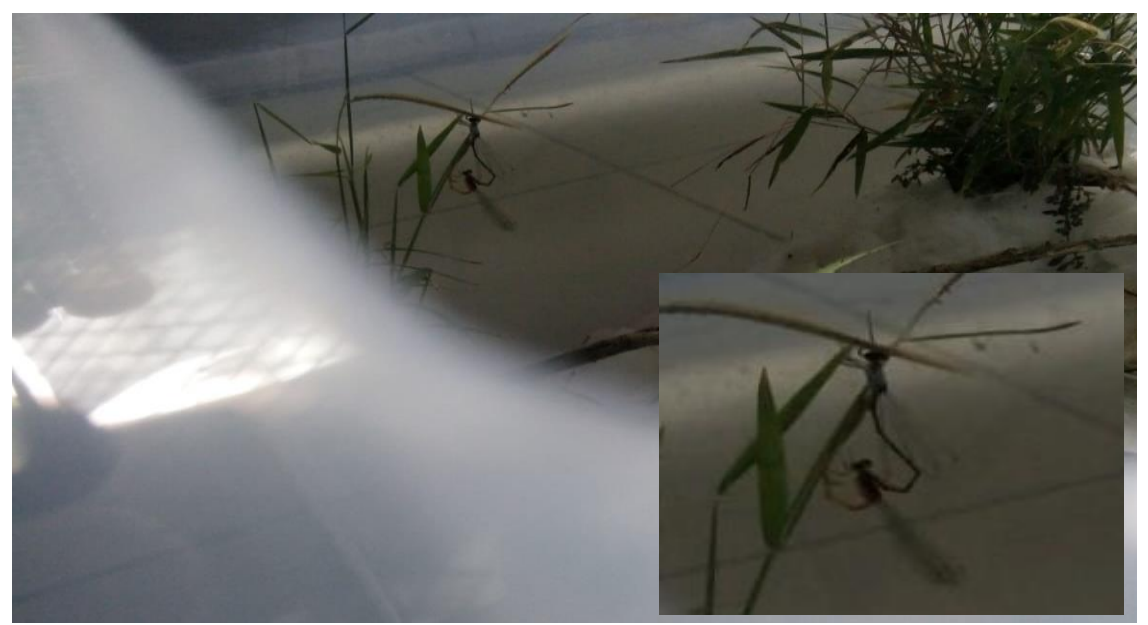

Figure 4. Mating A. femina in large cage on 17 October 2020. Insert: male (top) and female (bottom) in wheel position

Rearing dragonflies or damselflies within artificial setup seems to be easier to conduct in temperate region (see Gossum et al., 2003 or Locklin et al., 2012). These insects, along with all other temperate organisms, have only spring and summer for commencing their reproductive cycle (Silsby, 2001). The urge to produce progeny within this short period of time may impose on their acceptance toward rearing setups as their breeding environment. Undertaking rearing effort onto tropical dragonflies possesses more challenges as a tropical environment supports them to breed all year, which in our opinion, creates somewhat resistance for the dragonflies to accept the artificial environment provided in the rearing setups. Hence, finding suitable methods to comfortably persuade them inhabiting artificial rearing setups becomes crucial.

\section{CONCLUSION}

Our observation hinted that the use of large box $(20 \times 23 \times 33 \mathrm{~cm})$ decorated with plants from aquatic habitat can be the best rearing cage for damselfly Agriocnemis femina. The feeding system used in this study gives benefits in reducing rearing workload, minimizing possible human disturbance and avoid distress on the damselflies. Future study should be directed into looking at the effectiveness of the large box setup in massive rearing or how it works on different damselfly species.

\section{ACKNOWLEDGEMENT}

The authors thank to Muhammad Giffari Aditama and Dimas Surya for their help with cage and feeding preparation, also to Rezi Rahmi Amolia for her assistance in identifying the ornamental plants used in this study. The gratitude also goes to students who work in Animal Taxonomy Laboratory, Biology Department of Universitas Andalas during the study performed, as they participated in monitoring the situation around the rearing arrangement. This study was made possible thanks to the "Beginner Researcher" provided by Faculty of Mathematics and Natural Sciences, Universitas Andalas with contract no. 03/UN.16.03. D/PP/FMIPA/2019, date 10 May 2019 that financed this study.

\section{REFERENCES}

Altman, J. (1974). Observational Study of Behavior: Sampling Methods. Behavior, 49 (3/4), 227-267. http://www.jstor.org/stable/4533591.

Bridges, C.B. (1933). Apparatus and Methods for Drosophila Culture. The American Naturalist 66 (704), 250-273. https://doi.org/10.1086/280430.

Bybee, S., Córdoba-Aguilar, A., Duryea, M. C., Futahashi, R., Hansson, B., Lorenzo-Carballa, M. O., Schilder, R., Stoks, R., Suvorov, A., Svensson, E. I., Swaegers, J., Takahashi, Y., Watts, P. C., \& Wellenreuther, M. (2016). Odonata (dragonflies and damselflies) as a bridge between ecology and evolutionary genomics. Frontiers in Zoology, 13(1), 1-20. https://doi.org/10.1186/s12983-016-0176-7.

Carruthers, R.I., Larkin, T.S., Firstencel, H., \& Feng, Z. (1992). Influence of Thermal Ecology on the Mycosis of a Rangeland Grasshopper. Ecology, 73(1), 190-204. https://www.jstor.org/stable/1938731

Carvalho, G. B., Kapahi, P., Anderson, D. J., \& Benzer, S. (2006). Allocrine modulation of appetite by the sex peptide of Drosophila melanogaster. Current Biology, 16(7), 692-696. https://doi.org/10.1016/j.cub.2006.02.064.Allocrine.

Chamber DL. (1977). Quality Control in Mass Rearing. Annual Review of Entomology, 22, 289-308. https://doi.org/10.1146/annurev.en.22.010177.00144 5

Cohen, A. C. (2018). Ecology of Insect Rearing Systems: A Mini-Review of Insect Rearing Papers from 1906- 
2017. Advances in Entomology, O6(02), 86-115. https://doi.org/10.4236/ae.2018.62008

Córdoba-Aguilar, A. (2008). Dragonflies and Damselflies: Model Organisms for Ecological and Evolutionary Research. Dragonflies and Damselflies: Model Organisms for Ecological and Evolutionary Research, 94(3), 1-304. https://doi.org/10.1093/acprof:oso/9780199230693. 001.0001.

Corbet PS. (1999). Dragonflies, Behavior and Ecology of Odonata. New York: Cornell University Press.

Gossum, H.V., Rivera, A.C., \& Sánchez. (2003). Observations on rearing damselflies under laboratory conditions. Animal Biology, 53(1),37:45. https://doi.org/10.1163/157075603769682567.

Hinks, C.F \& Erlandson, M.A. (1994). Rearing Grasshoppers and Locusts: Review, Retionale and Update. Journal of Orthoptera Research, 3, 1-10. https://www.jstor.org/stable/3503403.

Janra MN, Gusman D, Susanto A, Yatap H, Fahrudin A, Andriansyah F, Prameswara A and Herwina H, (2020). Keanekaragaman Hayati KPHL Seluma Odonata. Bengkulu: Dinas Lingkungan Hidup dan Kehutanan Provinsi Bengkulu.

Locklin, J. L., Huckabee, J. S., \& Gering, E. J. (2012). A method for rearing large quantities of the damselfly, Ischnura ramburii (odonata: Coenagrionidae), in the laboratory. Florida Entomologist, 95(2), 273-277. https://doi.org/10.1653/024.095.0205.

McCullough, E. L., Verdeflor, L., Weinsztok, A., Wiles, J. R., \& Dorus, S. (2020). Exploratory Activities for Understanding Evolutionary Relationships Depicted by Phylogenetic Trees: United but Diverse. The American Biology Teacher, 82(5), 333-337. https://doi.org/10.1525/abt.2020.82.5.333.

Mazzacano, C., Paulson, D., \& Abbott, J. (2014). Guidelines for Creating \& Managing Habitat for Dragonflies \& Damselflies. Portland, OR: Migratory Dragonfly Partnership.
Okude, G., Futahashi, R., Tanahashi, M., \& Fukatsu, T. (2017). Laboratory Rearing System for Ischnura senegalensis (Insecta: Odonata) Enables Detailed Description of Larval Development and Morphogenesis in Dragonfly. Zoological Science, 34(5), 386-397. https://doi.org/10.2108/zs170051.

Perry, J.C. (2011). Mating stimulates female feeding: testing the implications for the evolution of nuptial gifts. Journal of Evolutionary Biology, 24 (8), 1727-1736. 10.1111/j.1420-9101.2011.02299.x.

Rice, T. M. (2008). A review of methods for maintaining odonate larvae in the laboratory, with a description of a new technique. Odonatologica, 37(1), 41-54.

Roe, A. D., Demidovich, M., \& Dedes, J. (2018). Origins and History of Laboratory Insect Stocks in a Multispecies Insect Production Facility, with the Proposal of Standardized Nomenclature and Designation of Formal Standard Names. Journal of Insect Science, 18(3), 1-9. https://doi.org/10.1093/jisesa/iey037.

Setiyono J, Diniarsih S, Oscilata ENR and Budi NS. (2017). Dragonflies of Yogyakarta. Yogyakarta: Indonesian Dragonfly Society.

Silsby J, (2001). Dragonflies of the World. Washington DC: Smithsonian Institution Press.

Tilyard RJ. (1917). The Biology of Dragonflies. Cambridge University Press, United Kingdom.

Switzer, P. (2002). Using Dragonflies as Common, Flexible \& Charismatic Subjects for Teaching the Scientific Process. The American Biology Teacher, 64(2), 158-162. https://doi.org/10.1662/0002-7685(2007)69

Tsukamoto, Y., Kataoka, H., Nagasawa, H., \& Nagata, S. (2014). Mating changes the female dietary preference in the two-spotted cricket, Gryllus bimaculatus. Frontiers in Physiology, 5, 1-6. https://doi.org/10.3389/fphys.2014.00095. 